\title{
Is There a Midwestern Literature?
}

\section{Michael J. Rosen}

THE MORE I TRIED to bear down on the question, "Is there a Midwestern literature?," the more I identified with the medium in James Thurber's famous cartoon of the seance in which the rapt clairvoyant tells her client, "I can't get in touch with your uncle but there's a horse here that wants to say hello." Other attractions and distractions kept suggesting themselves, ways of describing (and dismissing) Midwestern literature with, for instance, one or another list of clichés commonly ascribed to the region. Could Midwestern literature be a homespun web of small towns, general stores, flat lands, immigrant ancestors, middle-class families and conservative tendencies? (Clichés, to earn their weight in fool's gold, must possess a fraction of-certainly not a whole-truth.) And I was plagued with the vague feeling that after all my brooding, I'd do little more than arrive at another characterizing, seemingly less cliché-ridden list of Midwestern literature's attributes.

And so I had to begin by answering this question, "no." I had to begin by positing, "No, there is no such body called Midwestern literature." Even though I am a writer in the Midwest and someone who directs a literary center and a bookstore designed to feature such regional writers and writing, I wanted the practical ignorance of the ancients who looked upon the undisciplined world with less proven superiority than plain suspicion. Rather than say "yes" and go about proving such a thing, and rather than list specific and favored books that should be on a Midwestern reading list, I wanted to start, as much as I could, with the blank sky over the Midwest. Then, by making out individual positions of light, I hoped to accumulate a figure for such a heavenly body of literature. The ancients required the word considered for this act, con sidereal, meaning to bring the stars together, and this is the sort of scrutiny I wanted to use: connect apparently random points (for we are vast, and vastly misrepresented) into a figure whose character traits might influence, like a zodiac sign, everything born under it. I wanted to employ the astrologer's tricks of squinting to force the dimmer, proliferating points into the background, of looking off to one side to force more reluctant points into the eye's rods, 
and of repeatedly applying the common, recognizable, indigenous shapes of our known world-silo, ear of corn, skyscraper, or some such archetype - in attempts to discover a figure that might best assemble this daunting randomness above us.

(But even more emboldening was Carol Bly's further endorsement of the stars as a genuinely Midwestern sign: "At night we make the best of stars: they are what we have instead of a horizonful of sea. They are our immensity.")

Therefore, I thought it essential to clear the air of obstructing, flustering, obscuring views; I had to find a place outside the city's bright lights or the impenetrable groves of academe. Undertaking this ordeal of philosophical logistics, I identified with Italo Calvino's Mr. Palomar, who, in order to locate a star in the sky's vault, required the additional encumbrances of "putting on and taking off eyeglasses, turning the flashlight on and off, unfolding and folding the large chart, losing and finding again the reference points." (Perhaps that offers a practical definition of most brands of scholarship.)

I am not, then, employing the word "literature" the way bookstore chains use it as a qualitative category, a synonym for "classics": those steadily selling, perennial books that remain constant while the space around them changes every season. Their "literature" is to be distinguished from "fiction": quick-selling, soon-to-be-remaindered books that change every season while their allotted space remains constant.

I am also banishing from our constituting canon those books that simply contain geographical information about the region, whether used as mere background (as in anywhere with a few writerly details) or as foreground (as in a study of itself that our bookstore can relegate to the token holdings in "nonfiction": social sciences, nature, photography, or travel). I don't mean to quibble over their claim to the word "literature," but I wish to confine our attention to the realms of fiction and poetry where, to paraphrase Diderot, the Midwest will not be the thing itself but the light in which the thing can be seen. Our books of Midwestern literature will offer information about ourselves and not about itself.

I am also declining the alternately engaging or academic question, "Are there Midwestern writers - authors born under the sign of the Midwest?" Obviously, writers live in the Midwest; some have written a body of work or a specific book that could be found within our purview, but we 
can hardly subsume everything written by that geographical congress as Midwestern literature. Neither would we want to exclude a book because it was written by a non-Midwesterner, however we define that - by birth, or by experience, or by something ineluctable like sensibility. Rather than haggle over what defines a person's claim to a region, I'll insist that our designs should attend the specific work itself.

In fact, the most unexpected and apt idea that occurred to me as I puzzled over this question, is that it is not the publisher, the writer, the book, or even the writer's story that earns a book its place in the Midwestern canon, but the readers who, collectively, determine it: Is there a Midwestern reader, a readership that chooses appealing, engaging, relevant books that might constitute this body of Midwestern literature? In other words, can the question of a Midwestern literature be best addressed by what appeals to a reader rather than by what occurs to us as writers, critics, or publishers? And can this tenuous but logical leap suggest another question: Could the current interest in Midwestern books extend to contemporary readers in general because such books satisfy a national interest, desire, or even hunger for a kind of writing that has been thwarted, abandoned, or exhausted elsewhere? One last way of posing this question: Could we say that these selected books of Midwestern literature are simply books in which a reader's satisfied interests are what characterizes the literature?

But before enumerating those attractive qualities that a reader might be looking for in Midwestern literature, I had to be rid of that field of distraction I mentioned earlier: the troubling and simplistic temptation to consider Midwestern literature the embodiment of a set of salient features, that would either exclude arguably significant works by insisting on the presence of, say, agricultural preeminence, or include irrelevant works by insisting on the importance of, say, the family unit. Consider, for instance, the characteristics of density, population size, and degree of development (a huge spectrum that would have to incorporate farmland, a county seat, the river towns, the metropolis, the industrial complex). Can the Midwest find an emblematic value, a sign, by connecting St. Louis, Minneapolis, Cleveland, Chicago, Milwaukee, and Indianapolis - a few of the larger lights? Wouldn't the constituent values of that set be a more accurate compilation of large city traits, sharing more in common with other large cities throughout the nation than with the Midwest as a 
whole? Wouldn't that be "Urban Literature"? Would our emblem for the Midwest be any more accurate if our connections were drawn only through Leroi, Illinois; Prairie City, Iowa; Circleville, Ohio; Oshkosh, Wisconsin; and Morocco, Indiana? In this group, wouldn't the common properties show greatest affinity to those of other small-sized towns, even those near the coasts? Wouldn't that be "Rural Literature"? And what shall we do with those bright points (on the map or in the sky) that don't quite fit into our first or second constellation but whose fixity, like a planet, is undeniable? Is Ann Arbor more like a Midwestern town or any town where a major university has shaped the population? Would a book set there be in our canon? Is the character of Detroit governed more by its placement in the Midwest or by the last seventy-five years of the automobile industry? Isn't Detroit more like other places where a given industry (rubber in Akron, cereals in Battle Creek) has conscripted the lives of its inhabitants? Would a book set in Detroit be in our canon?

You can see the increasing discomfort that comes with each attempt to secure an identifiable trait for the region, even if I say that such a trait can represent the full, complementary range - the rural and the metropolitan, and the magnetic field that exists between and because of their polarities. To choose an image as "representative" must disclaim, as in a travel brochure, that there's just too much variety to show, just too little space here to do justice-ending with a phrase like you'll just have to see it for yourself. (Here, again, we imply that the visitor, the viewer or, in our tentative library, the reader is the necessary presence for the real sighting.)

Photographs of this typical Midwest might be a way of arguing away any last temptation to characterize. There is a limitation with any visual depiction, and since photography deals in documentary, its seeing is less believing than belittling: What is shown is necessarily less than what there is. Cropped from the context of their surroundings, their surroundings cropped from what surrounds it, any photograph offers us a singular aspect of a wild context. And this selection is photography's genius, the sample that helps to illuminate the whole. But the clichés of Midwestern literature are readily seen in their photographic kin: lovely aspects of unlovely places - places inhabited, for the most part, by the disconsolate, lackluster, inconsequential, and innervated. Yes, the Midwest contains such elements as dispirited bus stations, box-shaped, concrete block repair shops, lonely expanses of empty streets, and quaint, out-dated signagebut I resist the idea that desuetude and decrepitude, the behind-the-times 
and in-need-of-repair that might charm a photographer's attention, can characterize the Midwest any better than the gleaming, International-style building complexes can tell about the skyscraper's origin in Louis Sullivan's Chicago.

Mr. Palomar suggests that the way to identify a constellation, "the decisive proof is to see how it answers when you call it. More convincing than the matching of distances and configurations with those marked on the chart is the reply that the luminous dot gives to the name by which it has been called, its promptness in responding to that sound, becoming one with it." The stars become "necessary" and "salient" when the right name is found. From this convincing idea, I wanted each element or star in this Midwestern body to answer when called. Therefore, any book that deserves our Midwestern call numbers will have to be a book that integrates the individual within the contexts of family, community, neighborhood, and even local politics, so that each concentric or contiguous element shapes and is shaped by the others. A place of interdependency, a product of individual choices that insist on a given place. Quite simply, in a Midwestern book, place would provide a solution to an individual's place in the world-even when it appears to provide a problem. It would answer its name when a reader called it.

The endemic qualities of a particular setting would create a living system bent on self-preservation (however threatened), a system that would provide a means of understanding and assimilating the enormous, overwhelming world that impinges upon that place. And for the first time in history, I think that readers in America must acknowledge the rest of the transmitted world. The book we are speaking of would show the effect of whatever news it both creates and receives in its particular place. I suppose this stems from my sense that literature is untimely journalism, news that comes later, after whatever has happened dawns on us. To reiterate, then, the literature we are defining should demonstrate the impact of the world upon a singular Midwestern place, should live within a particular settlement of news.

This is not to extol mere reveling in the idiosyncratic and locally colored, the peculiarities of locale and citizenry. No, our Midwestern book must transform those specific, unique details in order to trick us into accepting its conventions, seduce us into lowering our resistance, convince us to empathize with the essential human qualities that cross any such regional boundary. We, as readers, can embrace such nourishing, com- 
forting, and revelatory experiences only through the conduit of individual and local details that our senses can select from life's accompanying white noise (the onslaught of information, the numbing inundation of news, the manufacturing of mass culture). Our book works to sensitize the reader and reinforce his or her own sensitivities beyond the mere reading of a book. It accomplishes this by providing an apprehensible, organized world in which honest perception, rewarded attention, and clear thinking are acknowledged. (The complexity of our lives outside a book rarely provides such elegant or enhanced opportunities for self-discovery.) The Midwestern setting should not only affect the lives of its characters but also the lives of its readers. Here again, the reader is implied in the constellation.

This is not the exclusive province of Midwestern literature, to be sure, but it seems that regionality has found a particular receptivity of late, and this I would credit to a sense of place that exceeds the idea of "setting" we learned about in high school (a concept to be compared to and contrasted with character, plot, and theme). Instead, setting is that identifiable source that nurtures, expresses, and influences those other essay questions: character, plot, and theme.

And perhaps in the Midwest, that location is still an untapped resource of specificities, a place of unretold, unexhausted trappings that can yet catch a reader off-guard, can yet keep a reader reading, paying attention, paying heed. I suspect contemporary interest in the writing of other nations, the popularization of translated literature-South American, Eastern European, Australian, and so on-is not unlike this keen interest in the Midwest: readers seeking a more curious, unpredictable, devious, delighting literature that, because of its foreignness and novelty, offers the reader the ultimate reward of recognizing the vivid and extraordinary conditions to which the human spirit is subjected.

Flannery O'Connor wrote: “It is a great blessing, perhaps the greatest blessing a writer can have, to find at home what others have to go elsewhere seeking." She, of course, referred to Milledgeville, Georgia, but her words apply to the writers in the Midwest who have undertaken the finding of the foreign - "what others have to go elsewhere seeking"-in their own homes. William Maxwell compounds this idea in The Folded Leaf: "The great, the universal problem is how to be always on a journey and see what you would see if it were only possible for you to stay at home." In both instances, I think we can assume that the primary quality in such a book, what the reader feels most assuredly, is a sense that the home place is 
the lens through which things are focused, the vanishing point from which things are drawn, the language in which perception is wrought.

I'll suggest that the very popularity of Midwestern literature, the discovering of what has already been produced and what is just being produced, the novelty of a regional-voices series, and even the resurgence of the personal essay is being generated by readers who desire the presentation of a reachable literature whose values are recognizable and even heartening, if that can simply mean to "give heart," as in to revivify feelings, however complicated, frustrated, or elated each might be. The Heartland reader would be a reader interested in the values yet possible in the storytelling of this region, because he or she is tired of the bright lights of the big city and the cannibalizing of Manhattan. Fed up with receiving less than zero from a book about precocious, privileged, jaded youths (a novel, but frustrated attempt to find a naive, less arch voice), irritated with yet another new stylistic route to the Indies - this time from the point of view of the spices, and resentful of the fiction of inexpressible velleities, glowering disinclinations, and moot recognitions that leave us asking, Where are you calling from? What did I miss? Midwestern readers may deny it is their fault that the writer's world lacked gravity, seasons, a heaven, or any real location. Increasing numbers of conferences and symposia are being held to descry and discuss a body of literature that provides something different than these august and aggrieved expressions of style. Could it be that the proliferation and interest in regional literature is a will toward reading books about ourselves (and if there are not such books, toward writing them) because contemporary literature has not been telling our story, that is, when it has even deigned to tell a story?

Now that I'm in over my head, I might as well enjoy the plunge by proposing that Midwestern literature has less interest in experimentation and more in oral histories and dialogue, clear narrative and genuine conflict, and that this is attributable to the possibility that a vocation in writing for someone in the Midwest has been, until recently, less a recognizable, knowable choice. The creative writer was less available in the form of mentors, communities, creative writing classes, bookstores. There had been no cachet to being a Midwestern writer. Until the last two decades, writing as a voluntary enterprise (as opposed to technical writing or business writing) hasn't been held at any premium, except in elementary schools, or in some private colleges. The professions of fiction and poetry 
(as decidedly different from the widespread amateur's interest) weren't as imaginable, so that one critical aspect underlying much of Midwestern literature - and its popularity - could be this very ingenuousness about being a writer, a refreshing innocence about the plausibility of the Midwest as the seeting for literature. Perhaps this lack of a late style and its problematic thrashings is what appeals to contemporary readers. Furthermore, our Midwestern reader, as well, could possess this ingenuousness.

Of course, such a young generation of writers could err on the side of wistfulness, zeal, ineptitude, but those errors would still affect the reader differently than self-consciousness and discontentment with traditional forms of narrative. And to defend this idea of ingenuousness, or humility, I'll recall Flannery O'Connor to the witness stand: "To know oneself is to know one's region. It is also to know the world, and it is also, paradoxically, a form of exile from the world. The writer's value is lost, both to himself and to his country, as soon as he ceases to see that country as a part of himself, and to know oneself is, above all, to know what one lacks. It is to measure oneself against Truth, and not the other way around. The first product of self-knowledge is humility, and this is not a virtue conspicuous in any national character."

Perhaps it is humility on the part of writers that distinguishes Midwestern literature-a place where writers understand that their value is the value of their region. And perhaps it is this humility which allows readers an opportunity to sense themselves - I mean, both to employ their senses, and to sense themselves.

And so I have come upon Michael Martone's image of the Midwest as skin that he suggests in his essay "The Flatness." Consider a Midwestern book, consider the location it contains, the skin of the reader. It acts as a membrane that provides both a personal (an "I") and a collective (an "us") identity. It is permeable to (accepting of) some things, impermeable to (resistant to) others. It insulates, protects, stores. It acquires, bringing the sensation of temperature and pressure, discomfort and pleasure and most significantly, kinesthesia, placement and orientation at any given time. And as a result of all these properties, it creates homeostasis: a means of remaining compatible with or comfortable within a changing environment.

The Midwestern literature we are looking for is made of a compatibility, met expectations between reader and writer, experience and language, 
which requires the joining of Velcro's loops and hooks: the roughened loops of recognition (cycles, patterns, repetitions) that are needed to engage the hooks of surprise (snags, interruptions, points, poignancies). Whatever would be surprising about a book would engage the reader's ultimate recognition; whatever would be recognizable about the book, would engage the reader's initial surprise - so that, in the progress of reading, there is a continuous combination of linkages, a ladder to shared creation that is not unlike the recombining of DNA strands between the male and female genes.

I will leave you to assign your own shape to our Midwestern literature. I suppose I can accept, by way of conclusion, that I have found, by tracing with a flashlight, gazing skyward in my own backyard, and balancing Thornton Wilder, William Maxwell, Toni Morrison, Wright Morris, James Purdy, Willa Cather, Mr. and Mrs. Bridge, and several other armloads of books, the Sign of the Reader - an earthly figure after all, a grounded rather than a lofty sign. Leaving you to assign your own figure, is a last return to this figure of Midwestern literature existing under the Sign of the Reader. After Mr. Palomar's evening of star gazing, his "twisting toward the south or toward the north, every now and then turning on the flashlight and holding the charts to his nose ... craning his neck backwards" and so on, he looks up to discover that all around him, on the beach where he has been observing, a pair of lovers, a fisherman, a customs man, and a boatman. These real people have populated the ground around him like earthly constellations. And he himself realizes that "a few paces from him a little crowd has gathered, observing his movements like the convulsions of a madman." Mr. Palomar, the observers of constellations, has become a necessary star in this zodiac: The Madman. The Writer. Mr. Palomar answers when the name of the star is called.

And so I am left finding a body of readers that makes the call numbers of Midwestern literature, that calls into the body of literature for works that answer. For the reader, there may be the North Star above, but he or she also holds the earth-bound North of a compass needle that, regardless of the distance traveled or the foreign surroundings, provides orientation, a constant from which to begin a return. In each book on our shelves of Midwestern literature, I believe we can sense this compass needle, and whether the characters consult it or not, it points to the home place, where readers, wherever they are reading in this vast and vastly misrepresented world, can find themselves. 